UNCORKING THE PAST 
This page intentionally left blank 


\section{UNCORKING THE PAST}

THE QUEST FOR WINE, BEER, AND OTHER ALCOHOLIC BEVERAGES

PATRICK E. MCGOVERN

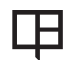

UNIVERSITY OF CALIFORNIA PRESS BERKELEY LOS ANGELES LONDON 
University of California Press, one of the most distinguished university presses in the United States, enriches lives around the world by advancing scholarship in the humanities, social sciences, and natural sciences. Its activities are supported by the UC Press Foundation and by philanthropic contributions from individuals and institutions. For more information, visit www .ucpress.edu.

Every effort has been made to identify the rightful copyright holders of material not specifically commissioned for use in this publication and to secure permission, where applicable, for reuse of all such material. Credit, if and as available, has been provided for all borrowed material either on-page, on the copyright page, or in an acknowledgment section of the book. Errors or omissions in credit citations or failure to obtain permission if required by copyright law have been either unavoidable or unintentional. The author and publisher welcome any information that would allow them to correct future reprints.

University of California Press

Berkeley and Los Angeles, California

University of California Press, Ltd.

London, England

(C) 2009 by The Regents of the University of California

Library of Congress Cataloging-in-Publication Data

McGovern, Patrick E.

Uncorking the past : the quest for wine, beer, and other alcoholic beverages / Patrick E. McGovern.

p. $\mathrm{cm}$.

Includes bibliographical references and index.

ISBN: 978-0-520-25379-7 (cloth : alk. paper)

I. Alcoholic beverages-History. 2. Alcoholic

beverages-Social aspects. 3. Drinking of alcoholic

beverages-History. 4. Drinking of alcoholic

beverages-Social aspects. I. Title.

$\mathrm{GT}_{2} 884 \cdot \mathrm{M}_{3} 62009$

394.I' 3 - dc22

2009010512

Manufactured in the United States of America

$\begin{array}{llllllllll}\text { I8 } & \text { I7 } & \text { I6 } & \text { I5 } & \text { I4 } & \text { I3 } & \text { I2 } & \text { II } & \text { IO } & 09\end{array}$

$\begin{array}{llllllllll}\text { IO } & 9 & 8 & 7 & 6 & 5 & 4 & 3 & 2 & \text { I }\end{array}$

This book is printed on Cascades Enviro IOO, a IOO\% post consumer waste, recycled, de-inked fiber. FSC recycled certified and processed chlorine free. It is acid free, Ecologo certified, and manufactured by BioGas energy. 
To the innovative fermented-beverage makers of our species 
This page intentionally left blank 